\title{
Changes in the distribution of Clouded Apollo Parnassius mnemosyne (Lepidoptera: Papilionidae) in Estonia
}

\author{
Ave Liivamägi, Valdo Kuusemets, Jaan Luig \& Kadri Kask
}

\begin{abstract}
Liivamägi, A., Kuusemets, V., Luig, J. \& Kask, K. 2013: Changes in the distribution of Clouded Apollo Parnassius mnemosyne (Lepidoptera: Papilionidae) in Estonia. - Entomol. Fennica 24: 186-192.

Clouded Apollo (Parnassius mnemosyne) has been occupying three separate areas in Estonia and has increased its abundance and population area remarkably during the last 30 years. Since the butterfly was first identified in the northeast (1878) and southeast (1984) of Estonia, the species has expanded its distribution with overall expansion distances of approximately 135 and $100 \mathrm{~km}$, respectively. In western Estonia, the butterfly was found locally on the island of Saaremaa in 1922-1973. Today, the butterfly is most likely extinct there. The occupational trend of the species in Estonia is not in accordance with its general trend in Europe, where it has shown a continuous decline. We suggest that in Estonia there is a suitable landscape structure with the presence of suitable landscape elements and still enough semi-natural grasslands that are suitable habitats for the butterfly even despite the fact that the traditional extensive agricultural practice in general is decreasing in Estonia.
\end{abstract}

A. Liivamägi, V. Kuusemets, J. Luig \& K. Kask, Institute of Agricultural and Environmental Sciences, Estonian University of Life Sciences, Kreutzwaldi 5, Tartu, 51014, Estonia; Corresponding author's e-mail: ave.liivamagi@emu.ee

Received 1 October 2011, accepted 13 February 2013

\section{Introduction}

Many European butterfly species are endangered, and their distribution has declined during recent decades (Van Swaay et al. 2010). One widely distributed and endangered specialist species that has received much attention over recent decades and that has been well studied by several researchers (Konvička \& Kuras 1999, Meglécz et al. 1999, Luoto et al. 2001, Välimäki \& Itämies 2003, Meier et al. 2005, Gratton et al. 2008, Gorbach \& Kabanen 2010) is Clouded Apollo, Parnassius mnemosyne (Linnaeus 1758). Over the entire distribution range, this Palaearctic species has discrete populations. In Northern Europe, the species occurs in flat semi-natural grass- lands (Luoto et al. 2001, Meier et al. 2005), but in Central Europe, it is found in forest steppes, sparse deciduous forests and forest clearings (Konvička \& Kuras 1999).

The distribution and abundance of Clouded Apollo has declined in North Europe, e.g. Finland (Väisänen \& Somerma 1985), Sweden (Bergström 2005), Norway (Aagaard \& Hansen 1992), and in Central Europe (Konvička \& Kuras 1999). However, there are few studies providing evidence in which $P$. mnemosyne has increased its abundance and expanded its distribution area (see Gorbach \& Kabanen 2010).

Due to the vulnerability of the populations of Clouded Apollo and due to several reports about local extinctions or the limited distribution of 
populations (Bergström 2005), the species is protected in Europe by the Bern Convention, the EU Habitat Directive Natura 2000 (CEE Habitat Directive 43/92, annex IV), and national protection acts, and it is included in many regional Red Data Books. In Estonia, the butterfly has been under legal protection since 1995 .

Clouded Apollo has been occupying three geographically separate areas in Estonia: west, northeast and southeast. In accordance with a regional separation, three subspecies have been described: P. mnemosyne osiliensis (Bryk 1922) in Saaremaa Island; P. mnemosyne estonicus (Viidalepp 2000) in north-eastern Estonia, and P. mnemosyne viidaleppi (Kesküla \& Luig 1997) in south-eastern Estonia. The first record of P. mnemosyne in north-eastern Estonia was in 1878. In 1922 the butterfly was discovered on the island of Saaremaa and in 1984 in southern part of Estonia. The last information of the existence of the species on the island of Saaremaa is from 1973. During the same year, 2 individuals were caught and 30 were reported to be seen (Kesküla 1989). There are no later records from the area, despite that many entomologists have searched for the butterfly. The subspecies is probably extinct today. In two other parts of Estonia, Clouded Apollo has expanded its distribution.

The geographical distribution of Clouded Apollo is generally related to the distribution of its host plants and to certain environmental conditions required by the given species. The larva of the species is monophagous on the plant genus Corydalis. In Estonia, they mainly feed on the leaves of $C$. solida. Therefore, the distribution of Clouded Apollo depends on the distribution of its larval host plant species.

The other general factors that make a biotope suitable for Clouded Apollo are food resources for adults, suitable habitat patches and surrounding landscape structure. Due to the specific requirements of environmental and habitat conditions, populations of Clouded Apollo are in danger of becoming fragmented, which may lead to the extinction of the butterfly. Therefore, it is important to study the state and distribution changes of Clouded Apollo in different parts of its distribution.

The aim of this study was to examine the abundance and distribution changes of Clouded
Apollo in Estonia during the period of 1878 2010. Understanding the pattern of the distribution and abundance of the butterfly is necessary for planning effective conservation of the species.

\section{Material and methods}

We collected and organised all known records of the findings of Clouded Apollo in Estonia to a database. The database includes data from various sources, such as literature, insect collections, records from researchers and local surveys of the butterfly. Whereas the purpose of the studies and the collections of the butterfly have differed and have been performed by different groups of people (amateur lepidopterists, qualified lepidopterists, volunteers), there are several duplications of records and variation in the accuracy of data.

Most of the earlier records were more general, describing the name of the place or the description of the location using landmark features such as roads, rivers, trees and bushes, some of the data were described within a 10 x10 km UTM square. The accuracy of these data was several kilometres but at least $5 \mathrm{~km}$.

The records from years 1981-2010 were taken from the national periodical review called LepInfo (a publication of the Estonian Lepidopterologists' Society and the Section for entomology of the Estonian Naturalists' Society that collects all findings of most butterfly species in Estonia). The accuracy of these records is generally better than in the case of older data, because all records are fixed according to the coordinates of the Estonian national grid system $(10 \times 10 \mathrm{~km})$ and concurrently international UTM grid system. During the last ten years, records of the butterfly (and the exact position of the habitat patch) have been additionally collected by the authors of this paper using portable GPS units.

The accuracy differs among separate data sets but in all it is adequate for analysing the species distribution for the scale of the whole Estonian during the long time period (132 years) since the first record of Clouded Apollo in Estonia.

All descriptions of the findings of the butterfly were linked on a digital cadastral map of Estonia $(1: 10,000)$ to the common GIS database using MapInfo Professional 9.0. The database of 
Table 1. Summary of records of Parnassius mnemosyne in Estonia.

\begin{tabular}{|c|c|c|c|c|}
\hline Study periods & Regions & $\begin{array}{l}\text { No. of findings } \\
\text { per region }\end{array}$ & $\begin{array}{l}\text { No. of sites } \\
\text { per region }\end{array}$ & $\begin{array}{l}\text { No. of individuals } \\
\text { per site }\end{array}$ \\
\hline \multirow{3}{*}{ 1878-1969 } & $\mathrm{NE}$ & 32 & 8 & $1-44$ \\
\hline & W & 9 & 1 & $1-20$ \\
\hline & SE & - & - & - \\
\hline \multirow{3}{*}{ 1970-1979 } & $\mathrm{NE}$ & 12 & 6 & $1-17$ \\
\hline & W & 1 & 1 & - \\
\hline & SE & - & - & - \\
\hline \multirow{3}{*}{ 1980-1989 } & $\mathrm{NE}$ & 19 & 11 & $1-37$ \\
\hline & W & - & - & - \\
\hline & SE & 13 & 9 & $1-9$ \\
\hline \multirow{3}{*}{ 1990-1999 } & $\mathrm{NE}$ & 14 & 11 & $1-50$ \\
\hline & W & - & - & - \\
\hline & SE & 81 & 42 & $1-200$ \\
\hline \multirow{3}{*}{ 2000-2010 } & $\mathrm{NE}$ & 57 & 48 & $1-60$ \\
\hline & W & - & - & - \\
\hline & SE & 69 & 44 & $1-300$ \\
\hline
\end{tabular}

Clouded Apollo consists of data about the exact location of the findings (place name or coordinates if possible), class of accuracy on a 1-3 scale (1: exact location, 2: grid system coordinates, 3 : descriptive location), date and time of the observation, name of the observer, gender and the number of individuals if determined and counted, source of data and a short description of the habitat. For analyses of the distribution changes we divided our data into five study periods: 1878 1969, 1970-1979, 1980-1989, 1990-1999 and 2000-2010. The first period is longer than the rest, because there were only single records of the butterfly from this period.

Finally, for the general evaluation of the relations between the distribution of the butterfly and its larval food plant Corydalis solida, the distribution map of the plant species in Estonia was derived from the Atlas of the Estonian Flora where the data are displayed in a grid of $9 \times 11 \mathrm{~km}$ squares (Kukk \& Kull 2005).

\section{Results}

There are 307 records of Clouded Apollo in Estonia from the period $1878-2010$. Of the five study periods, most records of distribution $(82 \%)$ are from 1980 and later. Only 18\% of all records are from the period 1878-1979.

During the first study period 1878-1969, there are 41 records of Clouded Apollo, with the majority of them located in eight places in northeastern Estonia and only one location (Kübassaare) on the island of Saaremaa (Table 1). During the period 1970-1979, there are 13 records with the majority of them located in north-eastern Estonia and one on the island of Saaremaa. During these two study periods the number of individuals of $P$. mnemosyne seen at the sites of findings varied between $1-44$. During the period 1980-1989, there are 32 records in Estonia. The butterfly was registered 19 times in north-eastern and 13 times in south-eastern Estonia. Number of individuals varied between 1 and 37. During the period 1990-1999 and 2000-2010, there are 95 and 126 records of $P$. mnemosyne, respectively. Approximately two thirds of the findings from the last two study periods are locating in southeastern Estonia where the number of recorded individuals has reached 300 .

Changes in the distribution trends of Clouded Apollo in Estonia are shown in Fig. 1. During the period 1878-1969, the distribution of the butter- 


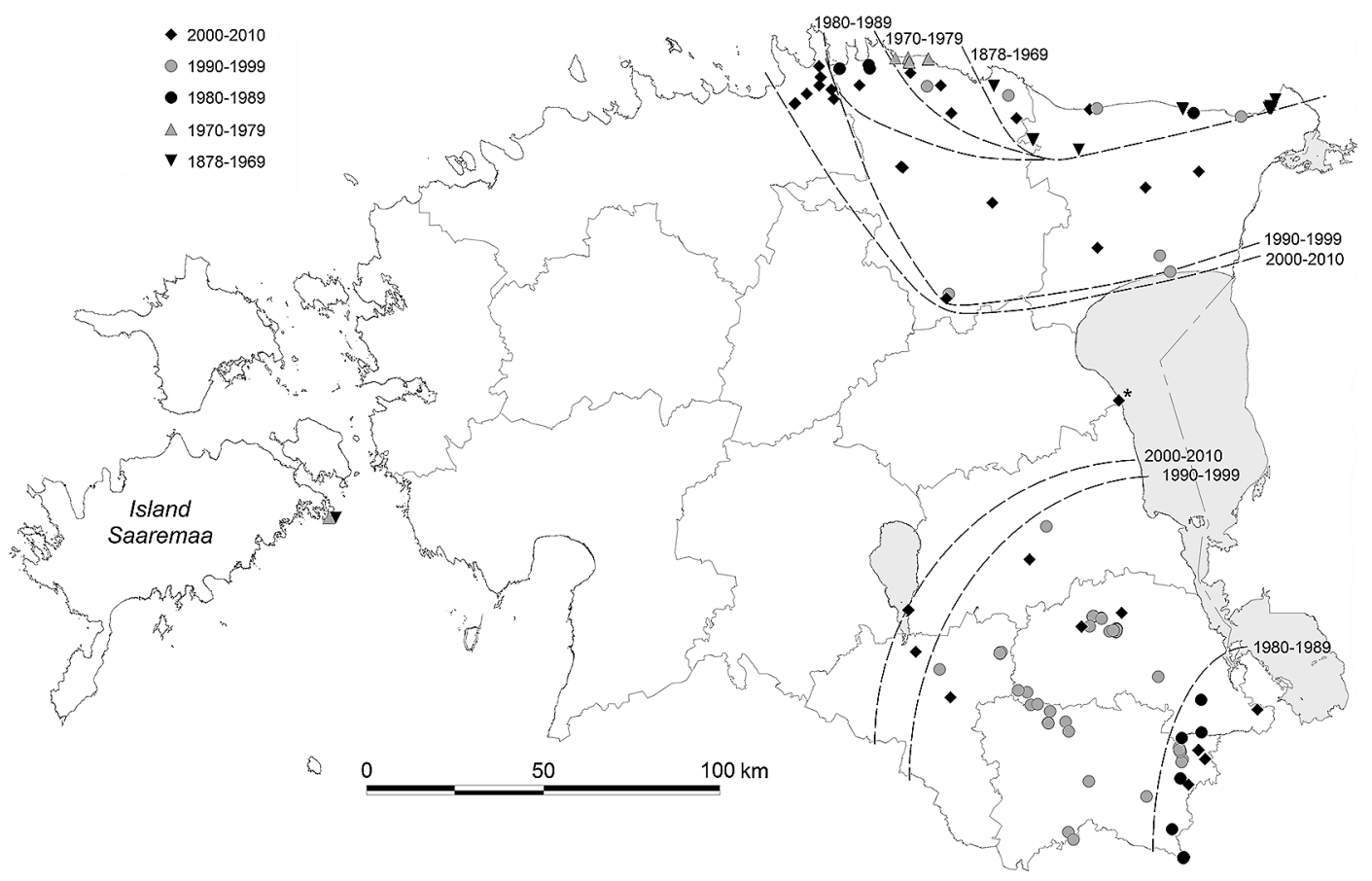

Fig. 1. Distribution of Clouded Apollo (Parnassius mnemosyne) in Estonia in 1878-2010. Broken lines show the extent of the butterfly distribution in a given period. The record with an asterisk $\left(^{*}\right)$ concerns a single instance from the year 2002 (5 individuals) with no records there later. Therefore, the 2000-2010 line was not drawn to include this record.

fly remained local in north-eastern Estonia. During the periods $1970-1979$ and $1980-1989$, the species moved westward, with decennial maximum expansion distances of approximately 30 $\mathrm{km}$ and $20 \mathrm{~km}$, respectively (Fig. 1). During the last two decades (1990-1999, 2000-2010) the expansion of the butterfly has continued to the west and to the south. In contrast, on the island of Saaremaa the butterfly was found during the period 1922-1973 but it remained local and few in numbers in its habitats over the entire period.

Until the middle of the 1980s, Clouded Apollo was found only in north-eastern Estonia and on the island of Saaremaa. In southern Estonia the butterfly was first recorded in 1984 near to the rivers Pedetsi and Piusa. Six years later, the butterfly was already found approximately 40 kilometres to the north in the Ahja River catchment and five years later approximately 35 kilometres to the northwest in the Võhandu River catchment. A more substantial increase, 30 to 50 $\mathrm{km}$ in occupancy to the north and north-westerly directions, was observed in the period 19902000 .
The distribution pattern of Clouded Apollo in Estonia and that of its larval host plant Corydalis solida are generally consistent (Figs 1 and 2). Corydalis solida is mainly growing in northern and south-eastern part of Estonia and in some areas on islands. The plant is almost missing in the central part of Estonia. Only in north-western part there are areas with $C$. solida but no findings of Clouded Apollo.

\section{Discussion}

The data sets used in our study differed in quality, but we consider their precision adequate for analysing the distributional changes of $P$. mnemosyne in the scale of whole Estonia during the long time period. However, one can suspect more representative recording effort in the recent data than in the older ones. We concur that recent recording tends to be more systematic and organised. On the other hand, entomologists had been visiting similar habitats suitable for $P$. mnemosyne also in earlier years, and a rare butterfly species has re- 


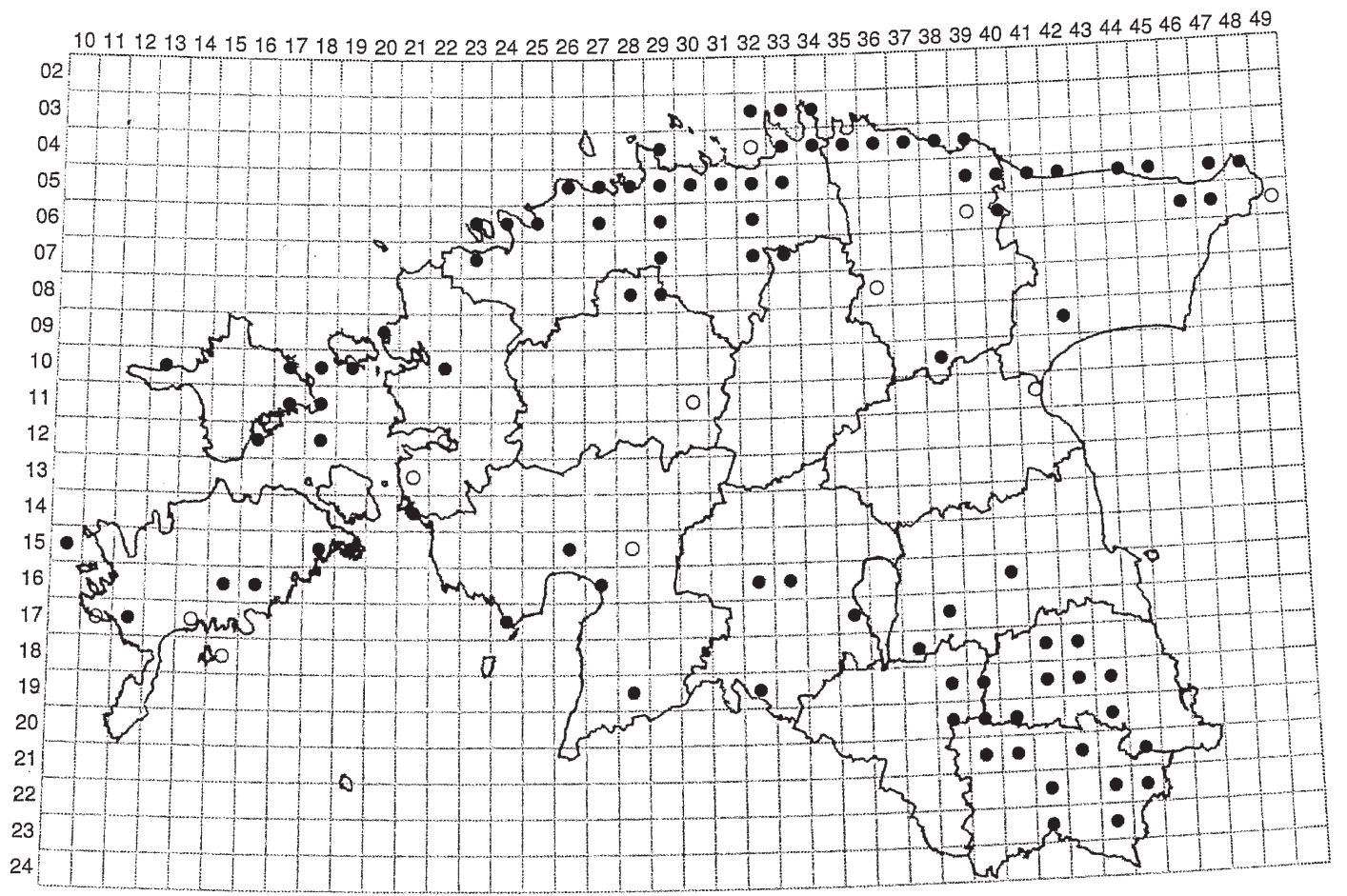

Fig. 2. The distribution of Corydalis solida in Estonia in 1921-2005 is displayed in a grid of $9 \times 11 \mathrm{~km}$ squares. Empty circle: recorded in 1921-1970; filled circle: recorded in 1971-2005 (Kukk \& Kull 2005).

ceived a lot of attention through the decades and is often recorded more carefully than common species. Therefore, we expect that presence of Clouded Apollo in certain areas would have been noticed whereas unrepresentative recording of $P$. mnemosyne especially in different locations is not the issue of this study. Additionally, there is no reason to doubt the study effort in the three regions of Estonia where the species is present. Since the area of the country is relatively small, practically the same amount of attention has been paid to butterfly research all over Estonia. It should be noted that the number of the lepidopterists has been almost the same through the times.

The general distribution pattern of Clouded Apollo in Estonia is in good agreement with the distribution of its larval host plant species. Interestingly, C. solida has not been recorded in central Estonia and most probably because of that the butterfly has neither been recorded there. Furthermore, this phenomenon offers a plausible explanation why the butterfly occupies three geographically separated areas in Estonia. Since there are rather long distances between these three regions and because the initial findings of the butterfly in the regions came from different years, we suggest that the colonisation of these three regions by Clouded Apollo took place from different directions. For instance, to North Estonia the butterfly probably expanded from Russia, to south-eastern Estonia from North-East Latvia or Russia (Pskov region) and to Saaremaa from western Latvia. This is supported by the general distribution areas of Clouded Apollo in neighbouring countries. However, there is no certain evidence for this interpretation and further investigation to clarify this is needed.

The results of this study showed that the specialist species Clouded Apollo has increased its abundance and distribution in Estonia. The general trend for most European grassland butterflies and also elsewhere for P. mnemosyne, is a decline in abundance and distribution area (Kuussaari et al. 2007, Settele et al. 2008). Habitat loss, deterioration of habitat quality, increasing fragmentation of habitat patches or combined effects of all these factors are the main threats to Clouded Apollo (Meglécz et al. 1999, Luoto et al. 2001, 
Bergström 2005). In Estonia, the extinction of the subspecies of Saaremaa Island has most likely been related to habitat degradation in particular locations and a lack of other suitable habitats in the vicinity. Therefore, a possible explanation of the pattern of contrasting trends of Clouded Apollo in different geographical regions is availability and quality of suitable habitats. Similarly to other European countries, the traditional extensive agricultural practice is decreasing in Estonia. In general, the area of semi-natural grasslands in Estonia has decreased from $1,571,000$ ha in 1939 to 130,000 ha in 2006 (Kukk \& Sammul 2006). However, the area of specific semi-natural grasslands that are suitable habitats for Clouded Apollo still remains high. This is particularly notable in the case of semi-natural riparian meadows with strips of alders that are the preferred habitat for C. solida and Clouded Apollo in Estonia (Meier et al. 2005). Therefore, the increasing occupancy trend of Clouded Apollo observed in recent decades is likely to be associated with the fact that there is still a good availability of seminatural grasslands, which are suitable for the butterfly. Additionally, Estonia has a good ecological network of natural communities and corridors, especially along rivers with riparian meadows that support the dispersal of Clouded Apollo. However, many suitable semi-natural grasslands are abandoned and have high risk of forest overgrowth, which could lead to higher pressure to the populations of Clouded Apollo in the future.

\section{Conclusions}

In this study, we provided an overview of the distribution of the threatened butterfly Clouded Apollo (Parnassius mnemosyne) in Estonia. During the last 30 years, the abundance and distribution area of Clouded Apollo has increased, except the subspecies on the island of Saaremaa has most probably gone extinct. On the other hand, a new record came from south-eastern Estonia in 1984, where the species had not been found previously. The exact reasons for the increase are unclear, but one can assume that the tendency is a combination of several factors, such as the presence of suitable habitats for the butterfly, the appropriate landscape structure with a sufficient density of habitat patches that support the dispersal of the butterfly. However, specific attention should be paid to avoiding the disappearance of suitable habitats of Clouded Apollo in the future.

Acknowledgements. We are very thankful to two anonymous reviewers for their useful comments that greatly improved the manuscript. This research was funded by targeted financing of the Estonian Ministry of Education and Research (SF1090050s07), by an applied research project of the Estonian Ministry of Agriculture (T8014PKPK) and by EU Regional Development Foundation, Environmental Conservation and Environmental Technology R\&D Programme project EDULOOD (3.2.0802.11-0043).

\section{References}

Aagaard, K. \& Hansen, O. 1992: Population studies of Parnassius mnemosyne (Lepidoptera) in Sunndalen, Norway. - In: Pavlicek, T., Ovaa, A. H. \& van der Made, J. G. (eds), Future of Butterflies in Europe: strategies for survival. Proceedings of the International Congress, held at Wageningen during April 12-15, 1989: 160-166. Agricultural University Wageningen, Wageningen. $326 \mathrm{pp}$.

Bergström, A. 2005: Oviposition site preferences of the threatened butterfly Parnassius mnemosyne - implications for conservation. - Journal of Insect Conservation 9: 21-27.

Bryk, F. 1922: "Parnassiana". Parnassius mnemosyne L. in Europa. Die estnische Form. - Societas Entomologica 37: 5-6.

Gorbach, V. V. \& Kabanen, D. N. 2010: Spatial Organization of the Clouded Apollo Population (Parnassius mnemosyne) in Onega Lake Basin. - Entomological Review 90: 11-22.

Gratton, P., Konopinski, K. \& Sbordoni, V. 2008: Pleistocene evolutionary history of the Clouded Apollo (Parnassius mnemosyne): genetic signatures of climate cycles and a time-dependent mitochondrial substitution rate. - Molecular Ecology 17: 4248-4262.

Kesküla, T. 1989: Has Parnassius mnemosyne become extinct in Saaremaa Island? — Eesti Loodus 3: 154. [In Estonian.]

Kesküla, T. \& Luig, J. 1997: Phenology and distribution of the Clouded Apollo Parnassius mnemosyne (Linnaeus, 1758) in Estonia, with the description of a new subspecies from south-eastern Estonia. - Atalanta 28: 17-20.

Konvička, M. \& Kuras, T. 1999: Population structure, behaviour and selection of oviposition sites of an endangered butterfly, Parnassius mnemosyne, in Litovelské Pomoraví, Czech Republic. - Journal of Insect Conservation 3: 211-223.

Kukk, T. \& Kull, T. 2005: Atlas of the Estonian Flora. Eesti Maaülikooli Kirjastus, Tartu. 500 pp. [In Estonian.] 
Kukk, T. \& Sammul, M. 2006: Area of seminatural Natura 2000 habitat types in Estonia. — Eesti Looduseuurijate Seltsi aastaraamat 84: 114-159. [In Estonian.]

Kuussaari, M., Heliölä, J., Pöyry, J. \& Saarinen, K. 2007: Contrasting trends of butterfly species preferring semi-natural grasslands, field margins and forest edges in northern Europe. - Journal of Insect Conservation 11: 351-366.

Luoto, M., Kuussaari, M., Rita, H., Salminen, J. \& von Bonsdorff, T. 2001: Determinants of distribution and abundance in the clouded apollo butterfly: a landscape ecological approach. — Ecography 24: 601-617.

Meglécz, E., Nève, G., Pecsenye, K. \& Varga, Z. 1999: Genetic variation in space and in time in Parnassius mnemosyne (L.) (Lepidoptera) populations in north-east Hungary: implications for conservation. - Biological Conservation 89: 251-259.

Meier, K., Kuusemets, V., Luig, J. \& Mander, Ü. 2005: Riparian buffer zones as elements of ecological networks: Case study on Parnassius mnemosyne distribution in Estonia. - Ecological Engineering 24: 531537.
Settele, J., Kudrna, O., Harpke, A., Kuhn, I., van Swaay, C., Verovnik, R., Warren, M., Wiemers, M., Hanspach, J., Hickler, T., Kuhn, E., van Halder, I., Veling, K., Vliegenthart, A., Wynhoff, I. \& Schweiger, O. 2008: Climatic Risk Atlas of European Butterflies. BioRisk 1: 1-710.

Van Swaay, C., Cuttelod, A., Collins, S., Maes, D., López Munguira, M., Šašić, M., Settele, J., Verovnik, R., Verstrael, T., Warren, M., Wiemers, M. \& Wynhof, I. 2010: European Red List of Butterflies. Publications Office of the European Union. Luxembourg. 48 pp.

Viidalepp, J. 2000: Clouded Apollo (Parnassius mnemosyne) in Estonia. - Teaduste Akadeemia Kirjastus, Tallinn-Tartu. 40 pp. [In Estonian.]

Väisänen, R. \& Somerma, P. 1985: The status of Parnassius mnemosyne (Lepidoptera, Papilionidae) in Finland. — Notulae Entomologicae 65: 109-118.

Välimäki, P. \& Itämies, J. 2003: Migration of the clouded Apollo butterfly Parnassius mnemosyne in a network of suitable habitats - effects of patch characteristics. — Ecography 26: 679-691. 